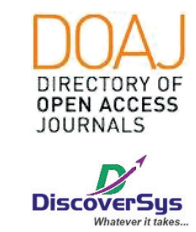

Published by DiscoverSys

\section{Hubungan antara persepsi mutu layanan kesehatan dengan kepuasan pasien rawat inap medis di RSU GMIM Pancaran Kasih Manado}

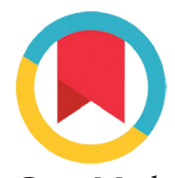

CrossMark

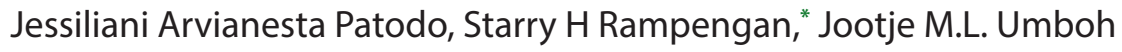

\section{ABSTRACT}

Background: Hospitals are currently required to provide health services according to optimal service standards. In hospital health services, patient satisfaction is one indicator of the quality of health services. Service quality is contributed by 5 principles, such as Service Quality, namely Reliability, Assurance, Tangible, Emphaty, Responsivenses. Methods: The research used analytic survey method, with cross sectional design. The research was held at GMIM Pancaran Kasih Manado hospital in January-March 2019. Samples taken from 150 respondents who fulfilling research questionnaires. Data analysis is univariate, bivariate, multivariate using chi-square, with $a=0,05$ dan $\mathrm{Cl}=95 \%$.

Results: The results of the research were, reliability $(p=0,000)$, Assurance $(p=0,530)$, Emphaty $(p=0,028)$, Tangible $(p<0,001)$ and Responsiveness $(p=0,855)$.

Conclusion: There was a relationship between reliability, empathy and tangible with patient satisfaction, while there was no relationship between assurance and responsiveness with satisfaction of medical inpatients at GMIM Pancaran Kasih General Hospital in Manado. Tangible factor became the most dominant variable associated with patient satisfaction.

Keywords: Perception of Quality, Patient Satisfaction, Hospital

Cite This Article: Patodo, J.A., Rampengan, S.H., Umboh, J.M.L. 2020. Hubungan antara persepsi mutu layanan kesehatan dengan kepuasan pasien rawat inap medis di RSU GMIM Pancaran Kasih Manado. Intisari Sains Medis 11(2): 434-438. D0I: 10.15562/ism.v11i2.768

\title{
ABSTRAK
}

Latar belakang: Rumah sakit saat ini dituntut untuk memberikan pelayanan kesehatan yang sesuai standar pelayanan yang optimal. Pada pelayanan kesehatan dirumah sakit kepuasan pasien merupakan salah satu indikator mutu pelayanan kesehatan. Mutu pelayanan dibentuk berdasarkan 5 prinsip yang dikenal dengan Service Quality yaitu kehandalan (Reliability), jaminan (Assurance), bukti langsung/ berwujud (Tangible), empati (Emphaty), daya tanggap (Responsivenses). Metode: Penelitian ini menggunakan metode survei analitik, dengan rancangan cross sectional. Penelitian ini dilaksanakan di Rumah Sakit GMIM Pancaran Kasih Manado pada bulan Januari-Maret 2019. Sampel penelitian ini berjumlah 150 responden dengan melengkapi kuesioner. Analisis data berupa univariat, bivariat dan multivariat menggunakan uji chi-square, dengan $a=0,05$ dan $\mathrm{Cl}=95 \%$.

Hasil: Hasil yang diperoleh dalam penelitian yaitu kehandalan $(p=0,000)$, jaminan $(p=0,530)$, perhatian $(p=0,028)$, bukti fisik $(p<0,001)$ dan daya tanggap $(p=0,855)$.

Kesimpulan: Terdapat hubungan antara kehandalan, perhatian dan bukti fisik dengan kepuasan pasien, sedangkan tidak ada hubungan antara jaminan dan ketanggapan dengan kepuasan pasien rawat inap medis di RSU GMIM Pancaran Kasih Manado. Variabel bukti langsung menjadi variabel yang paling dominan berhubungan dengan kepuasan pasien.
IImu Kesehatan Masyarakat PascaSarjana Universitas Sam Ratulangi Manado

\section{*Korespondensi:}

Starry H Rampengan, IImu

Kesehatan Masyarakat PascaSarjana

Universitas Sam Ratulangi Manado

starryh_rampengan@yahoo.com

Diterima: $15-03-2020$

Disetujui: $25-05-2020$

Diterbitkan: 19-06-2020

Kata Kunci: Persepsi Mutu Layanan, Kepuasan Pasien, Rumah Sakit

Cite Pasal Ini: Patodo, J.A., Rampengan, S.H., Umboh, J.M.L. 2020. Hubungan antara persepsi mutu layanan kesehatan dengan kepuasan pasien rawat inap medis di RSU GMIM Pancaran Kasih Manado. Intisari Sains Medis 11(2): 434-438. D0I: 10.15562/ism.v11i2.768

\section{PENDAHULUAN}

Setiap tenaga kesehatan yang bekerja di Rumah Sakit harus bekerja sesuai dengan standar profesi, standar pelayanan Rumah Sakit, standar prosedur operasional yang berlaku, etika profesi, menghormati hak pasien dan mengutamakan keselamatan pasien. Salah satu kewajiban rumah sakit ialah memberi pelayanan kesehatan yang aman, bermutu, anti diskriminasi, dan efektif dengan mengutamakan kepentingan pasien sesuai dengan standar pelayanan rumah sakit. ${ }^{1}$

Pada pelayanan kesehatan dirumah sakit kepuasan pasien merupakan salah satu indikator mutu pelayanan kesehatan. Kepuasan pasien menjadi bagian integral dan menyeluruh dari kegiatan jaminan mutu layanan kesehatan artinya, pengukuran tingkat kepuasan pasien harus menjadi kegiatan 
yang tidak dapat dipisahkan dari pengukuran mutu pelayanan kesehatan. ${ }^{2}$

Mutu pelayanan dibentuk berdasarkan 5 prinsip yang dikenal dengan Service Quality dikembangkan oleh Parasuraman, Zeithaml, dan Berry yaitu kehandalan (Reliability), jaminan (Assurance), bukti langsung/ berwujud (Tangible), empati (Emphaty), daya tanggap (Responsivenses). Lima dimensi ini mewakili persepsi pasien terhadap kualitas pelayanan jasa.

Hasil penelitian dari beberapa negara menunjukan data tentang tingkat kepuasan pasien. Tingkat kepuasan pasien menurut Ndambuki tahun 2013 di Kenya menyatakan 40,4\%, kepuasan pasien di Bakhtapur India menurut Twayana 34,4\%, sedangkan di Indonesia menunjukkan angka kepuasaan pasien 42,8\% di Maluku Tengah dan 44,4\% di Sumatra Barat. Berdasarkan Peraturan Kementrian Kesehatan Republik Indonesia Tahun 2016 tentang Standar Pelayanan Minimal untuk kepuasan pasien yaitu diatas 95\% (Kemenkes, 2016). Bila ditemukan pelayanan kesehatan dengan tingkat kepuasaan pasien berada dibawah 95\%, maka dianggap pelayanan kesehatan yang diberikan tidak memenuhi standar minimal atau tidak berkualitas. ${ }^{3}$

Observasi awal peneliti diinstalasi Rawat Inap Pavilium Hana dan Pavilium Lukas Rumah Sakit Pancaran Kasih diperoleh keluhan dari pasien dan keluarga pasien menyangkut beberapa hal dari kenyamanan ruang perawatan, waktu konsultasi dengan dokter yang kurang, kebersihan ruangan dan kamar mandi, demikian juga terdapat perawat kurang ramah dan kurang tanggap dalam memberikan pelayanan.

\section{METODE PENELITIAN}

Penelitian ini adalah penelitian kuantitatif yang bersifat survei analitik dengan pendekatan cross sectional study atau studi potong lintang. Penelitian ini dilakukan di Rumah Sakit Umum GMIM Pancaran Kasih Manado dan waktu penelitian dari Januari sampai dengan Maret tahun 2019. Sampel penelitian ini berjumlah 150 responden. Teknik pengambilan sampel adalah secara purposive sampling.

\section{HASIL}

\section{Karakteristik Responden dan Analisis Univariat}

Berdasarkan karakteristik responden dapat dilihat bahwa kelompok umur terbanyak berada pada kelompok umur 40-49 tahun yang berjumlah 41 responden $(27,3 \%)$ dan kelompok sedikit berada pada kelompok umur 20-29 tahun yaitu sebanyak 17 orang $(11,3 \%)$, jenis kelamin perempuan paling banyak yaitu 88 responden (58,7\%), sedangkan responden berjenis kelamin laki-laki sebanyak 62 responden (41,3\%), pekerjaan sebagai ibu rumah tangga paling banyak yaitu 61 responden $(40,7 \%)$, sedangkan tidak terdapat responden yang bekerja sebagai ABRI/POLRI dan responden yang memiliki pendidikan terakhir di SMA paling banyak yaitu sebesar 76 responden (50,7\%) paling sedikit SD sebanyak 16 responden (10,7\%).

reliabilitas baik Sebanyak 57 responden $(38,0 \%)$ sedangkan yang menyatakan reliabilitas kurang baik sebanyak 93 responden (62,0\%), responden yang memiliki jaminan aman yaitu 19 responden $(12,7 \%)$ sedangkan yang merasa tidak aman sebanyak $87,3 \%$ responden, responden yang mengalami perhatian baik sebanyak 15 responden (10,0\%) sedangkan yang mengalami perhatian kurang baik sebanyak 135 responden $(90,0 \%)$, responden yang menilai bukti fisik baik sebanyak 73 responden $(48,7 \%)$ sedangkan yang menilai bukti fisik kurang baik sebanyak 77 responden (51,3\%), responden yang menilai petugas kesehatan tanggap sebanyak 12 responden $(8,0 \%)$ sedangkan yang menilai kurang tanggap sebanyak 138 responden $(92,0 \%)$, dan responden yang puas sebanyak 65 responden $(43,3 \%)$ sedangkan yang tidak puas sebanyak 85 responden $(56,7 \%)$.

\section{Deskrispsi Analisis Bivariat a. Hubungan antara Kehandalan dengan Kepuasan Pasien}

Berdasarkan hasi uji Chi Square dapat diperoleh nilai probabilitas $=0,000$ artinya terdapat hubungan antara reliabilitas dengan kepuasan pasien. Ditandai dengan sebesar $62,0 \%$ yang menyatakan kehandalan kurang baik, $17,3 \%$ responden merasa puas dan $44,7 \%$ merasa tidak puas, sedangkan sebesar $38,0 \%$ responden yang menyatakan kehandalan baik, $26,0 \%$ responden merasa puas dan 12,0\% responden merasa tidak puas.

Penelitian ini sejalan dengan penelitian yang dilakukan oleh Putra (2016) mengenai pengaruh kualitas pelayanan terhadap kepuasan pasien rawat inap rumah sakit umum Cut Meutia Aceh Utara mengatakan bahwa terdapat hubungan yang signifkan antara kehandalan (reliability) dengan kepuasan pasien rawat inap. ${ }^{4}$ Penelitian lain yang sejalan dengan itu ialah penelitian yang dilakukan Tacoh (2016) menghasilkan bahwa terdapat hubungan antara pelayanan dokter dalam dimensi kehandalan dengan kepuasan pasien, dengan nilai signifikan pada variabel kehandalan berada dibawah $0,05(\rho=0,041) .^{5}$ 


\section{b. Hubungan antara Jaminan dengan Kepuasan Pasien}

Berdasarkan hasi uji Chi Square dapat diperoleh nilai probabilitas $=0,530$ menunjukkan bahwa tidak terdapat hubungan antara jaminan dengan kepuasan pasien rawat inap medis di rumah sakit umum GMIM Pancaran Kasih Manado. Dari total 150 responden, sebanyak 6,7\% responden yang merasa puas dengan jaminan aman sedangkan $36,7 \%$ responden yang merasa puas dengan jaminan tidak aman.

Penelitian yang sama dilakukan oleh Nurhaida (2015) yang menunjukkan bahwa tidak terdapat hubungan antara jaminan dengan kepuasan pasien rawat inap di rumah sakit umum daerah Ampana Kabupaten Tojo Una-Una dengan nilai $\rho=0,051$. Penelitian lain yang sejalan dengan penelitian ini ialah penelitian yang dilakukan oleh Bentelu (2016) mengenai faktor-faktor yang mempengaruhi tingkat kepuasan pasien peserta jaminan kesehatan nasional (JKN) menyimpulkan bahwa tidak ada pengaruh antara jaminan dengan kepuasan pasien peserta JKN dengan nilai signifikan $1,000(\rho>0,05){ }^{6}$

\section{c. Hubungan antara Perhatian dengan Kepuasan Pasien}

Berdasarkan hasi uji Chi Square dapat diperoleh nilai probabilitas $=0,028$ menunjukkan bahwa terdapat hubungan antara perhatian dengan kepuasan pasien rawat inap medis di rumah sakit umum GMIM Pancaran Kasih Manado. bahwa dari 150 responden, 135 responden (90,0\%) beranggapan kurang baik terhadap perhatian dari petugas layanan kesehatan sedangkan responden yang menjawab baik terhadap perhatian petugas layanan kesehatan lebih rendah. Penelitian ini juga sejalan dengan penelitian yang dilakukan oleh Surianti, dkk. (2014), dari total responden sebanyak 88 responden yang menyatakan bahwa empati terhadap kepuasan pasien di RSUD Polewali kurang yaitu 53 (60,2\%) sedangkan yang menyatakan empati terhadap kepuasan pasien cukup yaitu 35 responden $(39,8 \%){ }^{7}$

\section{d. Hubungan antara Bukti Fisik dengan Kepuasan Pasien}

Berdasarkan hasi uji Chi Square dapat diperoleh nilai probabilitas $=0,000$ menunjukkan bahwa

Tabel 1 Hasil uji regresi logistik variabel

\begin{tabular}{lccccc}
\hline & & & & \multicolumn{2}{c}{ 95\% C.I.for EXP(B) } \\
\cline { 5 - 6 } Variabel & Wald & Sig. & Exp(B) & Lower & Upper \\
\hline Kehandalan & 12,702 & 0,000 & 4,507 & 1,969 & 10,316 \\
Perhatian & 3,569 & 0,059 & 3,415 & 0,955 & 12,209 \\
Bukti Fisik & 26,814 & 0,000 & 8,817 & 3,868 & 20,098 \\
\hline
\end{tabular}

terdapat hubungan antara bukti fisik dengan kepuasan pasien rawat inap medis di rumah sakit umum GMIM Pancaran Kasih Manado. Hasil penelitian variabel bukti fisik menunjukkan bahwa dari 150 responden sebanyak 77 responden $(51,3 \%)$ menilai kurang baik bukti fisik yang ada di RSU GMIM Pancaran Kasih, sedangkan responden lainnya yang menilai baik lebih rendah.

Penelitian ini juga sejalan dengan penelitian yang dilakukan Tacoh (2016) di Rumah Sakit Umum Pusat Prof. Dr. R. D. Kandou Kota Manado tentang hubungan pelayanan dokter dengan kepuasan pasien rawat inap. Penelitian ini bersifat deskriptif analitik dengan menggunakan rancangan cross sectional menunjukkan bahwa dari total 85 responden paling banyak responden menilai tampilan bukti fisik tidak baik dibandingkan dengan responden yang menilai bukti fisk baik yaitu sebanyak 51 responden (54,9\%).

\section{e. Hubungan antara Daya Tanggap dengan Kepuasan Pasien}

Berdasarkan hasi uji Chi Square dapat diperoleh nilai probabilitas $=0,855$ menunjukkan bahwa tidak terdapat hubungan antara bukti fisik dengan kepuasan pasien rawat inap medis di rumah sakit umum GMIM Pancaran Kasih Manado.

Responden yang berpendapat ketanggapan kurang baik lebih banyak yaitu 138 responden $(92,0 \%)$ sedangkan responden yang berpendapat ketanggapan baik lebih rendah.

Penelitian ini sejalan dengan penelitian yang dilakukan oleh Putra (2016) mengenai pengaruh kualitas pelayanan terhadap kepuasan pasien rawat inap rumah sakit umum Cut Meutia Aceh Utara tahun 2016 menggunakan penelitian survei dengan pendekatan explanatory yang bertujuan untuk menjelaskan pengaruh kualitas pelayanan terhadap kepuasan pasien rawat inap RSU Cut Meutia Aceh Utara dengan sampel berjumlah 72 orang menunjukkan bahwa 39 responden (54,2\%) menyatakan ketanggapan kurang baik dan responden lainnya menjawab baik.

\section{f. Analisis Multivariat}

Tabel 1 menunjukkan hasil analisis multivariat pada variabel penelitian. Hasil analisis uji regresi logistik menunjukan bahwa variabel kehandalan $(\mathrm{p}=0,000)$ dan variabel bukti fisik ( $p=0,000)$ memiliki hubungan yang signifikan dengan kepuasan pasien rawat inap medis. Variabel bukti fisik menjadi variabel yang paling dominan yaitu dengan nilai $\operatorname{Exp}(B)$ 8,817 sehingga menyatakan bukti fisik memiliki kemungkinan 8 kali lebih besar hubungannya dengan kepuasan pasien rawat inap medis di RSU GMIM Pancaran Kasih Manado. 


\section{PEMBAHASAN}

\section{Hubungan Antara Kehandalan (Reliability) dengan Kepuasan Pasien}

Hasil uji statisik tabulasi silang menunjukkan terdapat hubungan antara kehandalan dengan kepuasan pasien rawat inap medis di rumah sakit umum GMIM Pancaran Kasih Manado.

Pada dasarnya petugas kesehatan dituntut dengan hasil kinerja sesuai dengan harapan pasien. Petugas kesehatan dirumah sakit umum GMIM Pancaran Kasih Manado baik dokter maupun perawat dianggap mempunyai kesiapan yang baik dalam melayani pasien, selalu memperhatikan perkembangan pasien selama berada diruang rawatan. Sementara itu, tidak sedikit pasien juga yang mengeluhkan mengenai proses penerimaan pasien dan waktu menunggu pasien untuk mendapatkan pelayanan rawat inap yang dinilai lambat. Hal itu terjadi karena rumah sakit umum GMIM Pancaran Kasih Manado merupakan rumah sakit tipe C yang berada di dalam kota Manado sehingga banyak dijangkau oleh masyarakat. Jumlah pasien yang banyak dengan ruang UGD dan ruang rawatan yang terbatas membuat pasien harus menunggu untuk dipindahkan diruang rawatan.

\section{Hubungan Antara Jaminan (Assurance) dengan Kepuasan Pasien}

Hasil penelitian variabel jaminan menunjukkan bahwa tidak terdapat hubungan antara jaminan dengan kepuasan pasien rawat inap medis di rumah sakit umum GMIM Pancaran Kasih Manado. Pada umumnya pasien menilai jaminan yang ada dirumah sakit umum GMIM Pancaran Kasih Manado sudah sesuai dengan harapan pasien. Mereka beranggapan bahwa tindakan yang dilakukan dokter dan perawat meyakinkan mereka untuk memperoleh kesembuhan atas sakit yang dideritanya berdasarkan dengan kompetensi dan skill yang dimiliki oleh petugas kesehatan. Ketelitian dan perhatian dalam memberikan pelayanan kesehatan yang maksimal dimiliki oleh petugas kesehatan rumah sakit umum GMIM Pancaran Kasih Manado.

Penelitian ini ditemukan bahwa terdapat responden yang mengaku pernah mengalami kesalahan pemberian obat dari petugas kesehatan. Hal seperti ini yang membuat persepsi pasien terhadap jaminan kesehatan rendah. Pasien menjadi kurang percaya dan khawatir hal itu akan terulang kembali sehingga dapat membahayakan kesehatan mereka.

\section{Hubungan Antara Perhatian (Emphaty) dengan Kepuasan Pasien}

Hasil uji statisik tabulasi silang menunjukkan terdapat hubungan antara perhatian dengan kepuasan pasien rawat inap medis di rumah sakit umum GMIM Pancaran Kasih Manado.

Hasil tersebut menunjukkan bahwa persepsi pasien mengenai perhatian sangat berhubungan dengan tingkat kepuasan pasien. Pasien menilai bahwa perhatian yang ditunjukkan oleh petugas kesehatan khusunya dokter dan perawat masih kurang. Bagi pasien perawat hanya sebatas mengerjakan yang menjadi tugas dan tanggungjawab mereka, tidak ada waktu lebih yang diberikan untuk berkomunikasi dengan pasien, sehingga pasien merasa perhatian yang diberikan masih kurang. Demikian halnya dengan dokter, waktu kunjungan dokter yang sangat terbatas membuat pasien tidak bisa berbicara atau berkonsultasi lebih mengenai penyakitnya. Mereka hanya percaya sepenuhnya kepada dokter dan perawat bisa menyembuhkan sakit yang diderita.

\section{Hubungan Antara Bukti Fisik (Tangible) dengan Kepuasan Pasien}

Hasil penelitian variabel bukti fisik menunjukkan bahwa terdapat hubungan antara bukti fisik dengan kepuasan pasien rawat inap medis di rumah sakit umum GMIM Pancaran Kasih Manado. Pada penelitian ini pasien beranggapan bukti fisik/tampilan yang ada dirumah sakit masih kurang. Hal itu ditandai dengan banyaknya pengeluhan pasien berkaitan dengan penampilan/bukti fisik rumah sakit seperti tidak tersedianya tempat sampah kering diruang rawatan atau kamar mandi sehingga pasien/keluarga pasien kesulitan untuk membuang sampah. Beberapa pasien lainnya mengaku bahwa ketika dipindahkan keruang rawatan tempat tidur tidak terpasang laken.

Penampilan fisik suatu rumah sakit dikatakan baik dilihat pula dari segi kebersihan ruangan, tempat tidur yang disiapkan, kebersihan ruangan dan fasilitas yang masih dalam keadaan baik dan tetap berfungsi. Selain itu, pasien juga menilai bahwa peralatan kedokteran yang ada di rumah sakit umum GMIM Pancaran Kasih Manado belum lengkap. Peneliti menilai harapan masyarakat sangat tinggi terhadap rumah sakit ini karena merupakan salah satu rumah sakit yang berada dipusat kota Manado sehingga mudah dijangkau oleh masyarakat. Ruang UGD yang kecil dan terasa sempit dengan jumlah pasien yang banyak juga menjadi keluhan bagi pasien. Disamping itu, tidak sedikit juga yang menilai baik terhadap penampilan dokter dan perawat. Mereka beranggapan bahwa perawat dan dokter bersih dan rapi setiap kali bertemu dengan pasien.

\section{Hubungan Antara Daya Tanggap (Responsiveness) dengan Kepuasan Pasien}

Penelitian ini menunjukkan bahwa tidak terdapat hubungan antara ketanggapan dengan kepuasan 
pasien rawat inap medis di RSU GMIM Pancaran Kasih Manado. Kenyataan dilapangan bahwa tenaga kesehatan baik dokter dan perawat mengerjakan tugas dan tanggungjwabnya dengan baik, mereka merespon cepat segala keluhan pasien. Hal tersebut dibuktikan dengan rendahnya komplain pasien yang berhubungan dengan ketanggapan petugas kesehatan baik yang ada pada kotak saran maupun penyampaian secara langsung.

Karakteristik rumah sakit ini juga merupakan rumah sakit keagamaan sehingga prioritas perhatian pasien tidak lagi pada hal-hal seperti itu. Sikap baik dan ramah yang ditunjukkan petugas kesehatan kepada pasien membuat pasien memiliki kesan baik terhadap rumah sakit. Perawat yang selalu siap 24 jam di nurse station untuk memantau perkembangan dan memenuhi segala kebutuhan pasien.

Pasien juga mengungkapkan bahwa dokter selalu bersikap ramah kepada pasien dan selalu bertanya keadaan pasien walaupun waktu konsultasi yang sangat terbatas. Pasien dan keluarga pasien juga merasa puas terhadap informasi yang diberikan oleh perawat atau petugas kesehatan lainnya pada saat mereka membutuhkan informasi. Informasi yang disampaikan jelas dan mudah dimengerti oleh pasien.

\section{KESIMPULAN}

Berdasarkan hasil penelitian, terdapat hubungan antara kehandalan, perhatian dan bukti fisik dengan kepuasan pasien, sedangkan tidak ada hubungan antara jaminan dan ketanggapan dengan kepuasan pasien rawat inap medis di RSU GMIM Pancaran Kasih Manado. Variabel bukti fisik merupakan variabel paling berhubungan (dominan) dengan kepuasan pasien.

\section{SARAN}

1. Meningkatkan pengawasan terhadap kebersihan dan kerapihan ruangan perawatan pasien termasuk memastikan kesiapan ruang rawatan telah bersih dan rapi untuk siap ditempati pasien.

2. Melakukan pengadaan tempat sampah kering disekitaran ruang rawatan termasuk kamar mandi untuk memudahkan pasien dan mencegah pasien/keluarga pasien membuang sampah sembarangan serta melakukan tambahaham bed khususnya di UGD sehingga pasien tidak lagi duduk dikursi untuk menunggu tindakan dan memperhatikan alat-alat kesehatan yang harus ada di rumah sakit.

3. Meningkatkan sikap empati dokter dan perawat terhadap pasien sehingga pasien merasa diperhatikan dan merasa puas terhadap pelayanan rumah sakit.

4. Meningkatkan fokus petugas kesehatan untuk melayani pasien sehingga mengurangi bahkan meniadakan kesalahan-kesalahan atau error yang dapat ditimbulkan sehingga pasien dapat percaya penuh terhadap semua pelayanan yang diberikan rumah sakit.

5. Meningkatkan respon cepat petugas kesehatan dalam menangani keluhan-keluhan yang disampaikan oleh pasien.

\section{DAFTAR PUSTAKA}

1. Pemerintah Indonesia. Undang-Undang Republik Indonesia Nomor 44 Tahun 2009. tentang Rumah Sakit. Jakarta: Sekretariat Negara; 2009.

2. Murtiana. Hubungan Mutu Pelayanan Kesehatan dengan Kepuasan Pasien BPJS di RSUD Kota Kendari Tahun 2016. Skripsi. Kendari: Universitas Haluoleo; 2016. Diakses tgl 28 September 2018 melalui ojs.uho.ac.id

3. Riska. Analisis tingkat kepuasan pasien terhadap pelayanan keperawatan dan faktor-faktor determinannya di ruang rawat inap RSUD dr. Rasidin Padang Tahun 2017. Sumatera Barat; 2017. Diakses tgl 15 Oktober 2018 melalui scholar.unand.ac.id

4. Putra. Pengaruh Kualitas Pelayanan Terhadap Kepuasan Pasien Rawat Inap Rumah Sakit Umum Cut Meutia Aceh Utara Tahun 2016. Tesis. Medan: Universitas Sumatera Utara; 2016. Diakses tgl 11 September 2018 melalui repositori.usu.ac.id/handle/123456789/821.pdf

5. Tacoh, T.S. Hubungan antara Pelayanan Dokter dengan Kepuasan Pasien di Instalasi Rawat Inap A Badan Layanan Umum Rumah Sakit Umum Pusat Prof. Dr. R. D. Kandou Kota Manado. Skripsi. Manado; 2016. Diakses 25 Januari 2019 melalui http://fkm.unsrat.ac.id

6. Bentelu, I.D. Faktor-Faktor yang Mempengaruhi Tingkat Kepuasan Pasien Peserta Jaminan Kesehatan Nasional di Instalasi Rawat Jalan Rumah Sakit Umum GMIM Pancaran Kasih Manado. Tesis. Manado: UNSRAT; 2016.

7. Surianti, dkk. Kepuasan Pasien di Ruang Rawat Inap Rumah Sakit Umum Daerah Polewali. Skripsi. Makassar: UNHAS; 2014.

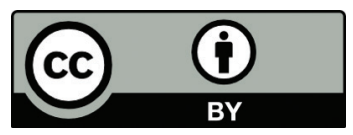

This work is licensed under a Creative Commons Attribution 